\title{
Human Trafficking: Breaking the Military Link
}

\author{
Keith J. Allred *
}

Over 140 years after slavery was outlawed in the United States, ${ }^{1}$ and nearly eighty years after world leaders signed the Slavery Convention, human slavery and enforced servitude continue to doom millions to lives of involuntary servitude in our day. ${ }^{2}$ The U.S. State Department's 2005 Report on Human Trafficking estimates that 600,000-800,000 persons are trafficked across international borders every year. ${ }^{3}$ Many more, perhaps millions, are trafficked within the borders of their own nations. ${ }^{4}$ The International Labor Organization estimates that there are about 12.3 million people enslaved in various kinds of forced or bonded labor, sexual or involuntary servitude at any given time. ${ }^{5}$ Some are kidnapped, while others are enticed by promises of good jobs abroad. Some are sold to traffickers by their parents or husbands; many simply migrate of their own accord in search of work, and find themselves in the hands of traffickers. Like the slaves of times past, many labor in fields and factories, yet a more pernicious form of human bondage has become the most common form of servitude: sexual slavery. ${ }^{6}$

Like slave owners of old, modern traffickers use violence, threats, intimidation, the confiscation of travel documents, and physical restraint to keep slaves at their tasks. Yet modern human trafficking seems more pernicious than the chattel slavery of the past, in part because it is so thoroughly the province of transnational organized crime. Human trafficking is considered to be the third-largest source of criminal income worldwide, generating an estimated $\$ 9.5$ billion per year. ${ }^{7}$ It is also closely linked with money laundering, document forgery, drug trafficking and human smuggling, and international ter-

* Keith Allred is Professor of Law at the George C. Marshall European Center for Security Studies in Garmisch-Partenkirchen, Germany; and holds the rank of Captain, Judge Advocate General's Corps, U.S. Navy. The views expressed herein are those of the author, and not those of any government or agency thereof.

1 The Emancipation Proclamation, which was signed in September of 1862 and became effective on 1 January 1863 for those Confederate states that had seceded from and not returned to the Union, was the first definitive step taken by the United States federal government toward abolition of slavery within its borders, http:/www.archives.gov/exhibits/ featured_documents/emancipation_proclamation/. Slavery was finally abolished by the Thirteenth Amendment to the U.S. Constitution, ratified on 6 December 1865.

2 The Slavery Convention entered into force on 9 March 1927; the Protocol of 7 December 1953 entered into force on 7 June 1955, with 95 parties to the Convention; see www.unhchr.ch/html/menu3/b/f2sc.htm.

3 U.S. Department of State, Trafficking in Persons Report, 2005 (Introduction); available at www.state.gov/g/tip/rls/tiprpt/2005/46606.htm (accessed July 2005). Ibid.

5 Ibid.

6 The State Department estimates that 80 percent of persons trafficked each year are women, and that 70 percent of these are trafficked into sexual slavery. Ibid.

7 U.S. Department of State, "Trafficking in Persons Report 2004," 14; available at www.state.gov/g/tip/rls/tiprpt/2004/34021.htm. 
rorism. ${ }^{8}$ This panoply of modern horrors is a plague that wreaks havoc upon society beyond the damage done to the lives of those who are enslaved.

Ironically, there continues to be a demand for cheap crops harvested by trafficked farm workers, cheap textile products produced by trafficked garment workers, and cheap sexual services provided by trafficked sex workers. While on one level society recoils at human trafficking and strives to destroy it, on another level society provides the demand, knowingly or not, for the cheap goods and services that trafficked persons provide. Yet in recent years the scourge of human trafficking has come increasingly before the public eye. Governments and international organizations have begun to recognize trafficking as a growing and pernicious evil. As it has come to be seen as a source of funding for crime and terror, governments and other organizations have begun to attack the factors that support it. This article will address only one aspect of the problem of human trafficking: the role of military personnel in creating demand for trafficked persons. Both the United States Army and UN peacekeeping forces have recently experienced embarrassments suggesting an unacceptable relationship between trafficked women and their soldiers abroad. The reactions of both organizations to these revelations have been both positive and strong. NATO, another significant source of troops deployed around the world, has joined the effort in a similar way. There is reason to hope that the combined initiatives of these three military forces will do much to reduce the demand for trafficked women and to increase the pressure placed on those who make commerce of trafficked persons. While the "war" on human trafficking must be fought on several fronts - including prevention, prosecution, and protection, and including enslaved individuals ranging from sweatshop and agricultural workers to child soldiers, and even camel jockeys ${ }^{9}$ - there are movements afoot that hold the promise of removing deployed military personnel as a significant factor in the demand for trafficked women.

\section{The United States}

Military personnel deployed away from their homes have been a long-standing source of demand for sexual services from local populations. During the Vietnam years, United States military personnel inspected and certified local prostitutes for service in Thailand, Vietnam, and the Philippines, and organized "Rest and Recreation" facilities for U.S. troops that included easy access to prostitutes. In some cases, an overly close proximity between U.S. troops and brothels has exposed the Army to allegations that it was essentially operating its own military houses of prostitution. ${ }^{10}$ Today, the United

Ibid.

9 In its 2005 Trafficking in Persons Report, the State Department indicates that humans are trafficked for all of these reasons.

${ }^{10}$ See, e.g. Emily Nyen Chang, "Engagement Abroad: Enlisted Men, US Military Policy and the Sex Industry," Notre Dame Journal of Law, Ethics, and Public Policy 15 (2001): 621, 62632; Katherine H. S. Moon, Sex Among Allies (New York: Columbia University Press, 1997); Susan Brownmiller, Against our Will; Men, Women and Rape (New York: Simon and Schuster, 1975), 93 et seq. 
States has nearly 250,000 members of its military forces deployed in combat and peacekeeping operations around the world. ${ }^{11}$ If the number of troops normally resident abroad is added to this total, there are nearly 350,000 Americans stationed in nearly 130 countries around the world. ${ }^{12}$ These sheer numbers may tend to make deployed U.S. military personnel one of the largest sources of demand for sexual services around the world, some of which would likely be provided by trafficked women. And yet the United States Army has begun to take steps to ensure that its troops do not contribute to this demand.

In May of 2002, Fox News broadcast a story suggesting that U.S. Army patrols of the red light districts in Korea were actually providing protection to establishments where trafficked women were "employed." 13 The suggestion that the U.S. Army was involved in facilitating the trafficking of sexual slaves was unmistakable, and provoked a strong reaction in Congress. Thirteen U.S. Congressmen asked the Inspector General (IG) of the Department of Defense to organize a thorough and comprehensive investigation into the relationship between U.S. armed forces and prostitution, including the prostitution of trafficked women. The IG responded quickly, with separate investigations into Korea and the Balkans. These reports, issued in July and December of 2003, did not find that U.S. troops were protecting the brothels or facilitating the trafficking of persons, but did agree that the Army's relationship with those establishments was "overly familiar" and that concerns about human trafficking had been overlooked. ${ }^{14}$ But the report also determined that many of the women working in those establishments had been trafficked, and that they had suffered such offenses as confiscation of personal identity papers and physical violence. ${ }^{15}$

Even the Inspector General's conclusion of an "overly familiar" relationship between human traffickers and the U.S. armed forces resulted in a pronounced response. The Defense Department established a "zero-tolerance" policy, which prohibited U.S. troops and the contractors who support them from being "complicit in any way in the

11 See www.globalsecurity.org/military/ops/global-deployments.htm.

12 Ibid.

13 Sarah E. Mendelson, Barracks and Brothels; Peacekeepers and Human Trafficking in the Balkans (Washington, D.C.: Center for Strategic and Security Studies, February 2005), 4042; Commission on Security and Cooperation in Europe News Release (15 September 2004), available at www.osce-ngo.net/040919.html; see also William H. McMichael, "Fighting Sex Slavery in Korea; Joint Command has Done Well Trying to Halt Practice of Human Trafficking, Report Says," Navy Times (23 August 2003), 26; Anni P. Baker, American Forces Overseas (Westport, CT: Praeger, 2004), 164.

14 Department of Defense Inspector General, "Assessment of DOD Efforts to Combat Trafficking in Persons, Phase I-Korea," page 10; available at www.dodig.osd.mil/aim/alsd/H03L8 8433128PhaseI.PDF; "Phase II-Bosnia Herzegovina," available at www.dodig.osd.mil/aim/ alsd/HT-Phase_II.pdf, accessed 21 July 2005. See also, Inspector General Joseph E. Schmitz, "Remarks as delivered to the OSCE Forum for Security Cooperation," Vienna, 17 November 2004; available at www.dodig.osd.mil/IGInformation/Speeches/OSCE_Forum_112204K.pdf.

DoD Inspector General, "Phase I-Korea," 8-10. 
trafficking in persons." ${ }^{16}$ The policy defines trafficking to include involuntary servitude and debt bondage, as well as sexual slavery. The commander of the U.S. forces in Korea also responded to the investigation with an expansion of the use of "off-limits" areas, prohibiting U.S. personnel from patronizing establishments that had been placed "off-limits" for suspected involvement in human trafficking. ${ }^{17}$ Military patrols of offlimits areas are now clearly instructed to prevent U.S. personnel from patronizing these establishments, and the appearance of U.S. forces providing protection for them is no longer remotely acceptable.

The zero-tolerance policy and expanded use of off-limits areas has been combined with an expanded education campaign for all U.S. troops reporting for duty in Korea. In testimony before the House Armed Services Committee given on 21 September 2003, General Leon LaPorte noted that all new arrivals, including U.S. Navy ships visiting Korean ports, are exposed to counter-trafficking training that alerts troops and sailors to the issue of trafficking, identifies off-limits areas, emphasizes the zero-tolerance policy, and describes potential disciplinary measures for violations. ${ }^{18}$ Other initiatives to reduce U.S. troops' patronage of establishments that may be involved in human trafficking include expanded recreational activities for military personnel on base; expanded cultural, service, and educational opportunities both on and off-base; a 24-hour hotline where military personnel can report businesses suspected of trafficking; self-produced TV advertisements seen by both U.S. and Korean populations that discuss the issue of trafficking; and a "Prostitution and Human Trafficking Identification Guidebook" that helps military personnel identify and avoid establishments that appear to be engaged in human trafficking. Courtesy patrols and undercover operations in areas where trafficking may be occurring further monitor the presence of U.S. personnel in these areas and discourage their patronage of prostitutes. ${ }^{19}$

The Army's embarrassed reaction to human trafficking in Korea may also have been on President Bush's mind when he addressed the United Nations General Assembly on 23 September 2003. He identified human trafficking as a "special evil" that merited the

16 Policy Memorandum "Combating Trafficking in Persons in the Department of Defense," 30 January 2004, signed by Deputy Secretary of Defense Paul Wolfowitz. See also Secretary Donald Rumsfeld memo of 16 September 2004, available at www.marshallcenter.org/sitegraphic/lang-en/page-mc-policy-1/static/xdocs/opa/static/SD\%20091604.pdf.

17 Statement of General Leon J. Laporte, Commander, United Nations Command, Commander, Republic of Korea-United States Combined Forces Command, and Commander, U.S. Forces Korea before the House Armed Services Committee, and Commission on Security and Cooperation in Europe of 21 September 2004, 1; available at www.defenselink.mil/dodgc/olc/ docs/test04-09-21LaPorte.pdf (accessed 21 July 2005).

18 Ibid., 2.

19 Ibid., 3-6. The general also reported that, between January and September of 2003, five military personnel had been punished for soliciting prostitution, and 398 had been given administrative punishments for violating curfews and off-limits area boundaries (ibid., 7). More than 600 bars, restaurants, and entire areas of town have been placed off limits. Rick Maze, "Army Targets Prostitution," Army Times, 4 October 2004; available at www.armytimes.com/print.php?f=1-ARMYPAPER-370025.php. 
UN's attention, devoting a substantial portion of his remarks to the topic. ${ }^{20}$ In February 2004, the President issued Executive Order 13257 establishing a task force to combat human trafficking. ${ }^{21}$ Later that month he issued a National Security Presidential Directive on trafficking that gave additional emphasis to the army's initiatives. ${ }^{22}$

In another remarkable innovation, on 15 September 2004 the Department of Defense's Joint Service Committee on Military Justice proposed several changes to the Uniform Code of Military Justice (UCMJ), a federal criminal code that applies to active duty military personnel worldwide, at all hours of the day, regardless of their deployment status. ${ }^{23}$ Under the UCMJ, U.S. military personnel can be tried for military offenses such as disrespect and failure to obey orders, as well as the more traditional criminal offenses. ${ }^{24}$ Among the proposals was a suggested new criminal offense of "patronizing a prostitute," intended to completely eliminate U.S. forces from the equation of demand for paid sexual services anywhere worldwide. Under the proposed legislation, patronizing a prostitute would become a crime for all military personnel after 1 July $2005 .^{25}$ The new offense would punish the soldier-customer even if the sex act is consensual and prostitution is legal in the country where the act occurs. ${ }^{26}$

20 President George W. Bush, "Remarks to the General Assembly of the United Nations," 23 September 2003, available at www.whitehouse.gov/news/releases/2003/09/20030923-4.html. Executive Order 13257 (18 March 2004) implements the Trafficking Victims Protection Reauthorization Act of 2003; available at www.whitehouse.gov/news/releases/2004/03/ 20040318-7.html.

22 Trafficking in Persons National Security Presidential Directive, 25 February 2003, available at www.whitehouse.gov/news/releases/2003/02/20030225.html. Uniform Code of Military Justice, 18 USC 801, et. seq.

2469 Federal Register 55600, at 55603-604. The elements of the offense of Patronizing a Prostitute will be:

a) That the accused had sexual intercourse with another person not the accused's spouse;

b) That the accused compelled, induced, enticed, or procured such person to engage in such act of sexual intercourse in exchange for money or other compensation;

c) That this act was wrongful;

d) That, under the circumstances, the conduct of the accused was to the prejudice of good order and discipline in the armed forces or was of a nature to bring discredit upon the armed forces.

A summary of the public comments received through 5 January 2005 is published at 70 FR 1877. For a detailed discussion of the development of these offenses, and the possibility that they might be imitated by other nations, see Michael F. Noone, "Trafficking in Women: The US Tactic: Prosecuting Military Customers. Could it be Exported?" (unpublished paper in possession of the author). On 5 January 2005, the proposal was forwarded, with public comments, to the Department of Defense. 70 Fed. Reg. 1877-1881, 11 January 2005; available at http://frwebgate3.access.gpo.gov/cgi-bin/waisgate.cgi?WAISdocID=945440211+0+0+0\&WA ISaction=retrieve (accessed July 2005). Department of Defense with public comments on 5 January 2005 for consideration. bin/waisgate.cgi?WAISdocID=945440211+0+0+0\&WAISaction=retrieve (July 2005). 


\section{NATO}

NATO has taken similar steps intended to remove its troops from proximity to, or an "overly familiar" relationship with, human trafficking, particularly for purposes of sexual slavery. In July 2003, the issue of NATO involvement in human trafficking appears to have been first raised by then-U.S. Ambassador to Moldova Pamela Smith, who indicated that peacekeepers stationed in the country created demand for prostitutes, which translated into demand for trafficked women. ${ }^{27}$ In March 2004, the U.S. and Norwegian Ambassadors to NATO, Nicholas Burns and Kai Eide, hosted the organization's first conference to address the problem of human trafficking, and to consider whether NATO personnel posted abroad were contributing to the demand. By June of that year, NATO had developed a draft "Policy on Combating Trafficking in Human Beings" that received the endorsement of NATO heads of state and governments. ${ }^{28}$ The NATO policy calls upon all NATO member states (and all non-NATO states that contribute troops or civilian personnel to NATO missions) to do all that they can to ensure that their troops do not contribute to or support trafficking in persons in any way. The key language of the policy prohibits NATO forces, contractors, and employees conducting operations under NATO command and control from "engaging in trafficking in human beings or facilitating it." ${ }^{, 29}$ Like the U.S. response in Korea, NATO sees training and education programs as being essential to reducing the engagement of prostitutes by NATO forces deployed abroad on NATO missions. Appendix II to the NATO policy outlines specific requirements of such training programs, including pre-deployment training for all, and special training for commanders and for military police units. ${ }^{30}$ The policy's prohibition also applies to any civilian element accompanying such forces, including contractors. ${ }^{31}$

\section{United Nations}

The Fox News report that caused such a reaction in the United States Army in Korea only hinted at official involvement in human trafficking. By contrast, the UN has been buffeted by allegations of serious sexual misconduct by its peacekeepers in many parts of the world for many years. Incidents of sexual assault perpetrated by UN peacekeepers have been documented in Angola, Cambodia, East Timor, Liberia, Mozambique,

27 Mendelson, Barracks and Brothels, 60.

28 NATO Press Conference, "Briefing on combating trafficking in human beings," 8 July 2004; available at www.nato.int/docu/speech/2004/s040708a.htm. The policy document and its annexes can be found at www.nato.int/docu/comm/2004/06-istanbul/docu-traffic.htm (accessed May 5 2005).

29 NATO Policy on Human Trafficking, paragraphs 5 and 6, at www.nato.int/docu/comm/2004/ 06-istanbul/docu-traffic.htm.

30

31 Ibid., Appendix I, Paragraph 3. 
Kosovo, Sierra Leone, and Somalia. ${ }^{32}$ When UN peacekeepers deployed to BosniaHerzegovina, brothels containing trafficked women developed quickly in the areas surrounding UN compounds. ${ }^{33}$ Former Human Rights Watch researcher Martina Vandenberg wrote, "Brothels sprouted like mushrooms, surrounding the base on all sides." 34 The UN suffered not only by the clear proximal association of prostitution and its troops, but by testimony regarding sexual offenses by its troops, and by testimony offered before a committee of the U.S. House of Representatives that high-level UN officials had attempted to conceal the offenses. ${ }^{35} \mathrm{UN}$ personnel also took with them hundreds of files regarding human trafficking when the UN mission in Bosnia turned over its duties to the European Union Police Mission at the end of 2002. This prevented evidence regarding trafficking that may have been embarrassing to the UN from falling into EU hands. ${ }^{36}$ At the very least, it represented an absolute failure of cooperation in the turnover.

These signal embarrassments were revived, if not eclipsed, in the spring of 2004 when allegations of peacekeeper misconduct surfaced in the Congo. Complaints that UN peacekeepers had committed sixty-eight instances of rape, pedophilia, and prostitution upon the Congolese people were bad enough, but they were aggravated by reports of peacekeepers interfering with the investigation, paying or offering to pay witnesses to change their testimony, threatening investigators, and refusing to identify colleagues who were suspected of offenses. ${ }^{37}$ Later research has concluded that up to 90 percent of the women engaging in normal prostitution in the Balkans were victims of human trafficking. ${ }^{38}$ As a result, not only were the peacekeepers engaged in rape and pedophilia,

32 Elizabeth Rehn and Ellen Johnson Sirleaf, Women, War and Peace: The Independent Experts' Assessment on the Impact of Armed Conflict on Women and Women's Role in Peace-building (New York: United Nations Development Fund for Women, 2002).

33 Julia Stuart, "Dark Side of Peacekeeping: Kofi Annan is Calling for UN Troops to be sent to Liberia," The Independent (London), (10 July 2003), 4, 5; Daniel Pallen, "Sexual Slavery in Bosnia; the Negative Externality of the Marketplace," Swords and Plowshare 13:1 (Spring 2003): 27-43; available at www.american.edu/sis/students/sword/Back_Issues/3.pdf (accessed 6 May 2003). The August 2004 list of off-limits places in Kosovo shows a clear correlation between the name of the establishment and the country responsible for that part of the country. Mendelson, Barracks and Brothels, 11. Mendelson, Barracks and Brothels, 14.

Testimony of David Lamb, U.S. House of Representatives Committee on International Relations, "The UN and the Sex Trade in Bosnia: Isolated Case or Larger Problem in the UN System," Hearings before the Subcommittee on International Relations and Human Rights. $107^{\text {th }}$ Congress, $2^{\text {nd }}$ Session (24 April 2002), 68; available at http://commdocs.house.gov/ committees/intrel/hfa78948.000/hfa78948_0f.htm (accessed 20 March 2005).

Mendelson, Barracks and Brothels, 63-64.

"Comprehensive Review of the Whole Question of Peacekeeping Operations in all their Aspects," UN General Assembly Document A/59/710 (24 March 2005): available at http://daccessdds.un.org/doc/UNDOC/GEN/N)5/247/90/PDF/NO524790.pdf?OpenElement (accessed 30 March 2005).

Mendelson, Barracks and Brothels, 9. 
they were, perhaps unknowingly, supporting the trade in trafficked women and feeding the coffers of organized crime. Counter-trafficking expert and former U.K. police inspector Paul Holmes indicates that peacekeepers who exploit trafficked women "unwittingly support precisely the people who do not want a safe, stable, and secure environment" - i.e., organized criminals. ${ }^{39}$

The Secretary-General of the UN was understandably outraged to learn that UN troops had committed these offenses while serving under the peacekeeping banner, but at the same time he could not have been surprised. He sent Jordanian Prince Zeid Ra'ad Zeid Al-Hussein to the Congo to investigate the allegations, and confirmed that they were true. The prince's report was released to the public in March 2005, featuring an objective report of the problem and its causes, as well as an outline of steps the UN and its member nations can take now to reduce or control it. ${ }^{40}$ The UN has thus found itself fairly in the limelight, with the opportunity to join the U.S. Army and NATO in seeking ways to prevent its troops from supporting trafficking or engaging in sexual misconduct while deployed on missions. The examples already set by the U.S. Army and NATO may well have informed and assisted development of the report's recommendations.

Unlike the U.S. military, which reports to a single chain of command and is governed by the UCMJ, UN (and NATO) forces are made up of troops from many nations, each under its own system of laws and rules of procedure. By virtue of the Status of Forces Agreement under which they serve, neither the host nation nor the UN has any power to impose punishment on these troops for their misconduct. This responsibility is reserved for officials of the state to which they belong. ${ }^{41}$ As a result, the system seldom works well, and peacekeepers are seldom punished for offenses allegedly committed and investigated while deployed on peacekeeping duties half a world away. And yet the Comprehensive Review looks at ways to improve the likelihood that discipline will be administered. Some of the most significant recommendations for removing peacekeepers from factoring on the demand side of the equation of the trade in trafficked persons include:

1. Require nations contributing troops to undertake, as a condition to offering peacekeepers, a legal obligation to seriously evaluate complaints against its peacekeepers and to take disciplinary action when warranted, reporting its actions to the Department of Peacekeeping Operations. ${ }^{42}$

2. Add to the performance goals of managers and commanders measures relating to the elimination of sexual exploitation and abuse. ${ }^{43}$

39 Ibid., 17.

40 Ibid.

41 Franz Cede and Lilly Sucharipa-Behrmann, The United Nations, Law and Practice (The Hague, London and Boston: Kluwer Law International, 1999), 100-101.

42 "Comprehensive Review," 6.

43 Ibid., 5. 
3. Impose strict disciplinary accountability for peacekeepers who violate the UN rules against exploitation and abuse. ${ }^{44}$

4.Employ modern forensic methods to identify suspects with fingerprint, fiber, and DNA analysis. ${ }^{45}$

5.Impose financial accountability on peacekeepers who father children while on deployment; use forensic equipment and technology to establish paternity.

6. Employ a permanent cadre of professional investigators, completely independent of other UN organs, to investigate allegations made against peacekeepers. Troop Contributing Nations (TCNs) should participate in the investigations to ensure that evidence collected will be admissible in their national courts. TCNs should agree to share information gathered in their own investigations with the UN investigators. ${ }^{46}$

7. Employ curfews and off-limits areas to ensure that civilians do not have access to peacekeeper camps and vice versa. Build recreational facilities for peacekeepers to provide an alternative to patronizing houses of prostitution. ${ }^{47}$

8. Establish a trust fund to compensate victims when a perpetrator cannot be identified. $^{48}$

Whether the UN is serious about reforming its peacekeeping operations or not remains to be seen, as the report and its recommendations have only just been issued. With the UN's history of peacekeeper abuses, obstruction of investigations, removal of evidence, its lack of common disciplinary authority, and an apparent organizational climate of cover up and obfuscation, it may well be that the report's recommendations will amount to nothing. So far, repatriation seems to be the only result that befalls any peacekeeper accused of crime. ${ }^{49}$ Even the prince's report admits that the perception that peacekeepers are never prosecuted for crimes that they commit while deployed overseas is "justified." 50

And yet there is room to be cautiously optimistic. The UN's humiliation comes at a time when other major military forces are also beginning to grapple with the connection between armed forces and trafficked women who are forced into prostitution. The connection between trafficking and organized crime, which threatens the security that peacekeepers are trying to establish, may add muscle to the effort to crack down on both peacekeepers and prostitutes. The knowledge that the proceeds of human trafficking are funding organized crime and terrorist operations may actually give national commanders the determination to make things different when the UN sends peacekeepers to the field. If this can be done - carefully, and without offending any Troop Con-

\footnotetext{
Ibid.

Ibid, 15

Ibid.

Ibid., 19-20.

Ibid, 22.

Mendelson, Brothels and Barracks, 68.

50 “Comprehensive Review," 17.
} 
tributing Nation - the results could significantly reduce the demand for trafficked women that UN Peacekeepers currently represent.

\section{Conclusion}

Human trafficking is one of the great scourges of our day, and is doubly damned because it feeds both organized crime and terrorist organizations. After a long slumber, nations of the world have begun to awaken and take firm and resolute action against both the demand and the supply sides of the equation. The role of military forces deployed abroad has come to be seen as a strong component of the demand for trafficked women, which in today's world is increasingly unacceptable to modern governments and the international organizations in which they participate. It is perhaps fortunate that the United States and United Nations have both suffered embarrassing revelations about the demand their deployed troops create for trafficked persons, particularly prostitutes. Whether mutually or independently, each has reached the conclusion that they must ensure that their military personnel must not be complicit in, or facilitate in any way, the trade in trafficked persons.

The steps taken by the U.S. and NATO (and those recommended for the UN) are clearly a step in the right direction, but how large a step remains to be seen. The task is not merely to give a brief training presentation before NATO troops deploy. It is to change the mindset of a whole society to the point where soldiers of every stripe actually see prostitution for what it is: a modern slave trade that fuels crime and instability and funds international terrorism. With strong leadership, disciplinary consequences that are real and significant, and other alternatives for off-duty recreation, there is a real possibility that deployed military personnel will diminish the role that they play in the demand for trafficked women. This in turn could do much to reduce the victimization of trafficked women and the evils that flow from this contemporary slave trade. 


\section{Bibliography}

Baker, Anni P.. American Forces Overseas . Westport, CT: Praeger, 2004.

Brownmiller, Susan. Against our Will; Men, Women and Rape. New York: Simon and Schuster, 1975.

Chang, Emily Nyen. "Engagement Abroad: Enlisted Men, US Military Policy and the Sex Industry." Notre Dame Journal of Law, Ethics, and Public Policy (2001): 15.

McMichael, William H.. "Fighting Sex Slavery in Korea; Joint Command has Done Well Trying to Halt Practice of Human Trafficking, Report Says." Navy Times (2003).

Mendelson, Sarah E., and Barracks and Brothels. Peacekeepers and Human Trafficking in the Balkans. Washington, D.C.: Center for Strategic and Security Studies, 2005.

Moon, Katherine H. S.. Sex Among Allies. New York: Columbia University Press, 1997.

Pallen, Daniel. "Sexual Slavery in Bosnia; the Negative Externality of the Marketplace." Swords and Plowshare 13, no. 1 (2003): 27-43.

Stuart, Julia. "Dark Side of Peacekeeping: Kofi Annan is Calling for UN Troops to be sent to Liberia." The Independent (2003). 